\title{
Asymmetric Effects of Real Exchange Rate on Trade Balance in Cote d'Ivoire: Evidence from Nonlinear ARDL Approach
}

\author{
Yaya $\mathrm{KEHO}^{1}$ \\ ${ }^{1}$ Ecole Nationale Supérieure de Statistique et d'Economie Appliquée (ENSEA) Abidjan. 08 BP 03 Abidjan 08, Côte \\ d'Ivoire.
}

Correspondence: Yaya KEHO, Ecole Nationale Supérieure de Statistique et d'Economie Appliquée (ENSEA) Abidjan. 08 BP 03 Abidjan 08, Côte d'Ivoire.

Received: February 4, 2021

Accepted: March 31, $2021 \quad$ Available online: April 19, 2021

doi:10.11114/aef.v8i3.5126

URL: https://doi.org/10.11114/aef.v8i3.5126

\begin{abstract}
This paper analyses the effects of real exchange rate on the trade balance in Cote d'Ivoire using times series from 1975 to 2017. Although many studies have investigated this issue, most of them assume that this relationship is symmetric. This paper relaxes this assumption employing the nonlinear autoregressive distributed lag (ARDL) model by Shin, Yu and Greenwood-Nimmo (2014). The results show that trade balance responds stronger to negative shocks in real exchange rate than to positive ones in the long-run, while the short-run response of trade balance is symmetric.
\end{abstract}

Keywords: trade balance, real exchange rate, nonlinear ARDL, Cote d'Ivoire

JEL Classification: C22, F10, F31, F41

\section{Introduction}

Since the adoption of floating exchange rates in the 1970s, the effectiveness of exchange rate depreciation in improving the trade balance is a subject of intense debate among economists. Following a devaluation of domestic currency, the import price rises while the export price falls, leading the trade balance to improve. However, the positive effect of devaluation on the trade balance depends on the price elasticity of imports and exports. The popular Marshall-Lerner condition demonstrates that for devaluation to improve the trade balance, the sum of the demand elasticities for exports and imports should exceed one. Despite the popular belief that real depreciation of domestic currency can improve the trade balance, the empirical evidence is mixed and inconclusive. The literature is awash with studies that tried to ascertain the impact of real exchange rate on the trade balance. While some studies supported the view that real exchange rate depreciation improves the trade balance (e.g., Kale, 2001; Baharumshah, 2001; Bahmani-Oskooee, 2001; Boyd, Caporale, \& Smith, 2001; Lal \& Lowinger, 2002; Musila \& Newark, 2003; Ogbonna, 2011; Igue \& Ogunleye, 2014), many others found a negative or insignificant relationship between the two variables (e.g., Rose \& Yellen, 1989; Rose, 1990; Bahmani-Oskooee, 1991; Upadhyaya \& Dhakal, 1997; Shahbaz, Awan, \& Ahmad, 2011; Akpansung \& Babalola, 2013; Oyinlola, Omisakin, \& Adeniyi, 2013; Eke, Eke, \& Obafemi, 2015).

Most of the earlier studies assume the effect of an exchange rate change on trade balance to be symmetric. This implies that depreciation and appreciation of real exchange rate of equal magnitude have the same effect on the trade balance. If this assumption does not hold, results from linear models may be misleading. Recently, studies have emerged to examine the possible asymmetry in the trade balance and exchange rate relationship. Several studies have argued that exporters and importers may behave differently to exchange rate changes. This can be attributed to adjustment costs, price rigidities, or quantity restrictions (Bussière, Callegari, Ghironi, Sestieri, \& Yamano, 2013). Accordingly, this paper re-examines the nexus between real exchange rate and trade balance in the case of Cote d'Ivoire using a nonlinear approach.

Cote d'Ivoire is a member country of the West African Economic and Monetary Union (WAEMU) which is made up of eight countries using the CFA franc as a common currency. The CFA franc was pegged to the French franc and the euro at a fixed rate since 1999. Over the period 1979-1993, Cote d'Ivoire recorded an economic growth rate of $-0.1 \%$. Also, the current account deficit increased from $10.6 \%$ of GDP in 1978 to $18 \%$ in 1980 and fall by $11 \%$ in 1993 . The surplus of trade balance decreased from $12.3 \%$ in 1987 to $7.1 \%$ in 1993 while the debt stock increased from $37.2 \%$ of GDP in 
1978 to $123 \%$ in 1993 . The external position was also characterized by a decline in foreign exchange earnings, overvaluation of the CFA franc exchange rate, accumulation of trade arrears, and debt overhang. To get out of these problems, Cote d'Ivoire and the other member countries of WAEMU adopted many structural adjustment programs in the 1980s. In january 1994, the CFA franc was devalued raising the parity rate from 50 CFA francs per French franc to 100 CFA francs per French franc. The real effective exchange rate depreciated by $43 \%$ in 1994. This devaluation was expected to increase the competitiveness of the economy. Following the devaluation of the CFA franc, Cote d'Ivoire registered a recovery with an economic growth rate of $7.73 \%$ in 1996. The trade balance surplus reached $16.4 \%$ in 1994 and $13.7 \%$ in 1996. However, from 1994 to 2009, the real effective exchange rate appreciated by about 24\%, resulting in a loss of competitiveness. Over the period from 1999 to 2011, Cote d'Ivoire experienced a long period of the political crisis resulting in an average economic growth rate of $0.5 \%$. With the end of the crisis in 2011 and the return of political stability, Cote d'Ivoire enjoyed remarkable economic progress, recording an economic growth rate of $8.8 \%$ during the period 2012-2017. This was achieved through increased imports of equipment, machines, and intermediate goods.

To the best of our knowledge, no known study has tested the asymmetry in the trade balance response to exchange rate in Cote d'Ivoire. The present study re-examines the issue by employing the nonlinear autoregressive distributed lag approach developed by Shin, Yu, and Greenwood-Nimmo (2014) and annual data from 1975 to 2017. Using this method, we seek to answer to the following questions. Does the exchange rate depreciation lead to a significant improvement in the trade balance? Do exchange rate depreciation and appreciation have distinct effects on the trade balance? The results of this study will contribute to the existing literature on the impact of the real exchange rate changes on the trade balance in African countries.

The rest of the study is structured as follows. Section 2 reviews the literature on the effect of real exchange rate on the trade balance. Section 3 outlines the econometric methodology of the study and describes the data. Section 4 discusses the empirical results. Section 5 concludes the study.

\section{Review of Literature}

The nexus between trade balance and the exchange rate has received a great deal of attention among economists over the past four decades. The popular Marshall-Lerner condition states that real devaluation of domestic currency will improve the trade balance if the sum of the demand elasticity for both exports and imports is greater than one (Marshall, 1923; Lerner, 1944). On the other hand, another contrasting view advocates that trade balance reacts differently to depreciation in the short and long-run. Theoretically, depreciation makes the domestic goods cheaper as compared to the foreign ones. This increases the volume of exports. As foreign goods become more costly, the volume of imports will reduce, improving the trade balance. However, exports and imports may not responsive at the initial period of depreciation of the exchange rate, as there is a lag period before both consumers and producers adjust to changes in relative prices (Junz \& Rhomberg, 1973; Krueger, 1983; Bahmani-Oskooee \& Ratha, 2004). Following a devaluation, the trade balance may deteriorate first and begin to improve after, leading to a J-curve effect (Magee, 1973).

A growing body of empirical studies investigated the impact of real exchange rate on trade balance using different econometric techniques. The evidence from this literature is mixed and inconclusive. For instance, Yol and Baharumshah (2007) applied panel cointegration to ascertain the effects of exchange rate changes on bilateral trade balance between 10 African countries and the U.S. They found that real exchange rate depreciation improves the trade balance of Botswana, Egypt, Kenya, Nigeria, Tunisia, and Uganda, but worsens that of Tanzania and has no effect in Ghana, Morocco, and Senegal in the long-run. Amzath, Drama and Shen (2010) examined the balance of trade of Cote d'Ivoire throughout 1975-2007. They found that real exchange rate depreciation improves the trade balance both in the short and long run. Adeniyi, Omisakin, and Oyinlola (2011) examined the case of four West African Monetary Zone (WAMZ) countries, namely The Gambia, Ghana, Nigeria, and Sierra Leone, for the period 1980-2007. Applying the bounds testing approach to cointegration, their results confirmed the J-curve effect only in Nigeria. In the cases of The Gambia and Ghana, real devaluation initially improves the trade balance and then deteriorates it later while no clear pattern was found for Sierra Leone. Rawlins (2011) studied the relationship between currency depreciation and trade balance of a panel of 21 Sub-Saharan African countries for the period 1995-2005. Using panel cointegration analysis, the study concluded that currency devaluation is an effective policy tool in improving the trade balance of most of these countries.

In the case of Nigeria, Ogbonna (2011), Umoru and Oseme (2013), and Igue and Ogunleye (2014) reported evidence supporting that exchange rate depreciation improves trade balance. On the other hand, Loto (2011) and Akpansung and Babalola (2013) found that depreciation of exchange rate does not significantly improve trade balance whereas Ogundipe et al. (2013), Oyinlola et al. (2013) and Eke et al. (2015) concluded that it leads to trade balance deterioration. Alege and Osabuohien (2015) explored the trade balance and exchange rate nexus for 40 Sub-Saharan African countries over the period 1980-2008. They found that the depreciation of domestic currencies does not stimulate trade, given the heterogeneous structure of the economies and export composition. Anning, Riti, and Yapatake (2015) used cointegration 
analysis and error-correction model to examine the exchange rate-trade balance nexus in Ghana. Using aggregated data from 1980 to 2013, they found that a real depreciation of the exchange rate causes a deterioration in Ghana's trade balance in the short-run followed by an improvement in the long-run. Caporale, Gil-Alana, and Mudida (2015) employed fractional integration and cointegration methods to Kenya over the period 1996-2011 and found supportive evidence of the Marshall-Lerner condition. Ogbonna (2016) applied cointegration analysis and vector error correction model to the trade balance of Benin for the period 1950-2008. He found that exchange rate depreciation has a long-run positive impact on the trade balance, but the J-curve effect does not hold in the short-run. Genemo (2017) investigated the effect of the exchange rate on the trade balance in selected African countries for the period from 1990 to 2014. Using panel cointegration techniques, he found that a depreciation of the real exchange rate deteriorates trade balance in the long-run.

Meniago and Eita (2017) studied the case of 39 Sub-Saharan African countries over the period 1995-2012. Using standard panel estimation methods, they found no significant relationship between exchange rate and trade balance. Yazgan and Ozturk (2019 considered the bilateral trade flows of 33 countries. They came out with the result that for the majority of the countries, a real depreciation of the exchange rate improves the home country's trade balance in the long-run. However, the short-run J-curve was not observed. Examining the case of Uganda using the bounds testing approach to cointegration, Kamugisha and Assoua (2020) found that the exchange rate has a significant effect on the trade balance in the short-run. Keho (2020) examined the impact of FDI on the trade balance in Cote d'Ivoire. Employing the ARDL bounds testing approach to cointegration, he found that domestic income, real effective exchange rate, and foreign direct investment are important drivers of the trade balance. Further, real depreciation of the exchange rate was found to improve the trade balance in both the long and short run. In a recent study, Keho (2021) confirmed the positive effect of real exchange rate depreciation on the trade balance of Cote d'Ivoire.

One common limitation of the above studies is the assumption of symmetry in the relationship between real exchange rate and trade balance. This assumption implies that exchange rate depreciation and appreciation cause the same effect in absolute value on the trade balance. The lack of consensus in the empirical literature could stem from this restriction. Consequently, studies have emerged in recent years to call for re-examining the asymmetry in the trade balance response to the exchange rate. Several theoretical studies have pointed out that exporters and importers may react in a nonlinear manner to changes in the exchange rate. Bussière et al. (2013) argued that asymmetry in the trade balance and exchange rate nexus can be attributed to adjustment costs, price rigidities, and quantity restrictions. In such a context, it might be misleading if the relationship between real exchange rate and trade balance is assumed symmetric.

With the development of new econometric techniques in recent years, series of studies have examined the possible asymmetry in the impact of exchange rate changes on the trade balance. Aliyu and Tijjani (2015) employed the threshold cointegration technique designed by Enders and Siklos (2001) to uncover the asymmetric nexus between exchange rate movements and trade balance in Nigeria. The results showed that the trade balance adjusts slowly in response to exchange rate depreciation, whereas it reacts quickly to exchange rate appreciations. They concluded that devaluation may not necessarily improve the trade balance. Bahmani-Oskooee and Fariditavana (2015) applied the nonlinear autoregressive distribution lag (NARDL) approach developed by Shin et al. (2014) and found that exchange rate movements have asymmetric effects on the trade balance in Canada, China, Japan, and the USA. Relying on the nonlinear ARDL model, Bahmani-Oskooee and Fariditavana (2016), Arize, Malindretos and Igwe (2017) and Bahmani-Oskooee and Kanitpong (2017) confirmed asymmetric effects of exchange rate changes on the trade balance. Iyke and Ho (2017) examined the experience of Ghana by using the linear and nonlinear ARDL approaches. They found no evidence in support of the short and long-run impact of exchange rate changes on the trade balance in the linear specification. In contrast, in the nonlinear model, real depreciation was found to improve the trade balance in the long-run, while real appreciation does not have any impact on the trade balance.

Recently, Akoto and Sakyi (2019) ascertained the determinants of trade balance in Ghana over the period 1984-2015. The results from both symmetric and asymmetric ARDL models showed that depreciation of domestic currency is not an appropriate tool to improve the trade balance. Further, the results indicated that household consumption expenditure, government consumption expenditure, and domestic prices have negative and significant effects on the trade balance in the long and short-run, whereas foreign income and money supply have positive and significant impacts in the short-run. Bahmani-Oskooee and Arize (2019) analyzed bilateral trade balance models of the US with each of her 20 trading partners from Africa. Using the linear and nonlinear ARDL models, they found support for the J-curve effect in three partners from the linear models and eight partners from the nonlinear models. Furthermore, they found short-run asymmetric effects of exchange rate changes in almost all models and significant long-run asymmetric effects in half of the partners. Bahmani-Oskooee and Baek (2019) studied the case of Korean bilateral trade with her 14 partners. Employing the nonlinear ARDL approach, they reported that in most cases, exchange rate changes have short-run and long-run asymmetric effects on the bilateral trade balance. Bahmani-Oskooee, Bose and Zhang (2019) examined the trade balance between the US and China at the commodity level. They applied the nonlinear ARDL approach and 
considered 97 commodities. They found significant short-run asymmetric effects in the case of two-third of the commodities, whereas one-third of the commodities which account for a large share of Sino-US trade were affected by significant long-term asymmetry. Bahmani-Oskooee and Arize (2020) examined the case of 13 African countries using the nonlinear ARDL model. Their results revealed asymmetric effects in many of the countries. Bahmani-Oskooee and Fariditavana (2020) focused on the bilateral trade balance of the US with Canada and considered 161 industries. The results provided evidence for asymmetric short-run effects in all industries and significant long-run asymmetric effects in 62 industries. Bahmani-Oskooee and Gelan (2020) considered the bilateral trade balance of South Africa with the US for 25 industries. They found short-run asymmetric effects in 19 industries, which last into long-run asymmetric effects in 14 industries. Nathaniel (2020) examined the case of Nigeria using the non-linear ARDL approach, and found that positive and negative shocks in the exchange rate are associated with detrimental impacts on the trade balance, but only the positive shocks are significant.

As can be seen from this review, the literature fails to reach a consensus on the effect of real exchange rate on the trade balance. Also, the empirical literature for Sub-Saharan African countries on the issue of nonlinearity between exchange rate and trade balance is scarce. This study aims to investigate the issue in the case of Cote d'Ivoire.

\section{Model and Methodology}

The empirical methodology of the study consists of three sub-sections. We first describe the empirical model of the trade balance to be estimated. Next, we outline the econometric methodology of the analysis. Lastly, we present a description of the data utilized for the estimations.

\subsection{Model Specification}

The objective of this study is to ascertain the effects of real exchange rate on the trade balance. Following existing studies, we compute the trade balance as the value of exports divided by the value of imports. This indicator allows the logarithmic transformation of the trade balance variable regardless of whether exports are greater or less than imports. Given this definition, the trade balance can be specified as follows:

$$
T B_{t}=\frac{P_{t} X_{t}}{P_{t}^{*} S_{t} M_{t}}
$$

where $\mathrm{X}$ stands for the volume of exports, $\mathrm{P}$ represents domestic price level, $\mathrm{M}$ stands for the volume of imports, $\mathrm{P}^{*}$ is foreign price level, and $\mathrm{S}$ denotes the nominal exchange rate. Taking the natural logarithm yields:

$$
t b_{t}=x_{t}-m_{t}-\left(s_{t}-p_{t}+p_{t}^{*}\right)=x_{t}-m_{t}-e_{t}
$$

where $e_{t}=s_{t}-p_{t}+p_{t}^{*}$ is the log of the real exchange rate. On the other hand, we define the long-run export and import demand respectively, as follows:

$$
\begin{aligned}
& x_{t}=\alpha_{1}+\beta_{1} y_{t}^{*}+\gamma_{1} e_{t} \\
& m_{t}=\alpha_{2}+\beta_{2} y_{t}-\gamma_{2} e_{t}
\end{aligned}
$$

where $y_{t}$ represents the logarithm of domestic income, $y_{t}^{*}$ is the logarithm of foreign real income, $\gamma_{1}$ and $\gamma_{2}$ represents the elasticities of export and import concerning prices, respectively. Using both equations and substituting them into the trade balance equation, we obtain the long-run trade balance equation:

$$
t b_{t}=\alpha+\beta_{1} y_{t}^{*}-\beta_{2} y_{t}+\gamma e_{t}
$$


where $\alpha=\alpha_{1}+\alpha_{2}$ and $\gamma=\left(\gamma_{1}+\gamma_{2}-1\right)$. Real devaluation of domestic currency will cause the trade balance to improve in the long run if $\gamma_{1}+\gamma_{2} \succ 1$.

Using Eq.(5) as the basis of our analysis, we specify the empirical model for trade balance function as follows:

$$
\ln T B_{t}=\beta_{0}+\beta_{1} \ln Y_{t}+\beta_{2} \ln Y F_{t}+\beta_{3} \ln R E R_{t}+\beta_{4} D 94_{t}+\mu_{t}
$$

where $\ln$ represents natural logarithm, TB is trade balance on goods and services as defined above, $\mathrm{Y}$ is the domestic income, YF is real income of trade partners or foreign income, RER is the real effective exchange rate, D94 is a shift dummy variable that takes the value of zero for the period before 1994 and one otherwise, and $\mu_{t}$ is an error term assumed to be a white-noise process.

The attractive feature of the log-linear specification is that the slope coefficient measures the elasticity of the trade balance concerning control variables. A priori, the coefficient of domestic income can either be positive or negative depending on whether domestic income is spent on domestic goods or foreign goods. If an increase in domestic income is spent on imported goods, the trade balance will worsen, otherwise, it will improve. Similarly, an increase in foreign income will improve trade balance if foreign income is demand-driven. Finally, a real devaluation of the domestic currency, that is, a decrease in the real exchange rate, is expected to encourage the demand for exports and discourage imports thereby improving the trade balance. Therefore, the coefficient on the real exchange rate is expected to be negative.

Eq.(6) assumes an asymmetric or linear relationship between real exchange rate and trade balance, that is the appreciation and depreciation of the real exchange rate have the same effect on the trade balance. Accordingly, it does not allow potential asymmetry or nonlinearity in the effect of exchange rate on the trade balance. As argued in the literature review, if the trade balance responds differently to depreciation and appreciations of the real exchange rate, then the linear specification may fail to establish a significant relationship between real exchange rate and trade balance. In this study, we re-examine the relationship between real exchange rate changes and trade balance using nonlinear models.

Following the modeling framework of Shin et al. (2014), we formulate an asymmetric trade balance model by decomposing the exchange rate variable into positive (appreciation) and negative (depreciation) changes as follows:

$$
\operatorname{lnRER}_{\mathrm{t}}=\operatorname{lnRER}^{0}+\operatorname{lnRER}_{\mathrm{t}}^{+}+\operatorname{lnRER}_{\mathrm{t}}^{-}
$$

where $\operatorname{lnRER}{ }^{+}$and $\operatorname{lnRER}{ }^{-}$denote, respectively, partial sums of the positive and negative changes in the real exchange rate. They are calculated as follows:

$$
\begin{gathered}
\ln R E R_{t}^{+}=\sum_{i=1}^{t} \Delta \ln R E R_{i}^{+}=\sum_{i=1}^{t} \max \left(\Delta \ln R E R_{i}, 0\right) \\
\ln R E R_{t}^{-}=\sum_{i=1}^{t} \Delta \ln R E R_{i}^{-}=\sum_{i=1}^{t} \min \left(\Delta \ln R E R_{i}, 0\right)
\end{gathered}
$$

Thus, the asymmetric trade balance model can be represented as follows:

$$
\ln T B_{t}=\beta_{0}+\beta_{1} \ln Y_{t}+\beta_{2} \ln Y F_{t}+\beta_{3}^{+} \ln R E R_{t}^{+}+\beta_{3}^{-} \ln R E R_{t}^{-}+\beta_{4} D 94_{t}+\mu_{t}
$$

where $\beta_{3}{ }^{+}$captures the long-run response of trade balance to the appreciation of exchange rate, whereas $\beta_{3}{ }^{-}$is the response of trade balance to real depreciation. This specification allows us to determine whether the effect of the real exchange rate on the trade balance is symmetric or asymmetric. If the two partial sums have the same coefficients in terms of sign and size, then the effect of real exchange rate on the trade balance is symmetric, otherwise, it is asymmetric or nonlinear. 


\subsection{Econometric Methodology}

The empirical investigation involves three steps. We first examine the stationarity of the variables using unit root tests. Second, we investigate the existence of a long-run relationship among the variables. The third step estimates the short and long-run effects of the real exchange rate on the trade balance. To depict the presence of a long-run relationship between the variables, we rely on the nonlinear ARDL (NARDL) approach introduced by Shin et al. (2014) as an extension of the ARDL bounds testing approach developed by Pesaran, Shin and Smith (2001). The advantages of the ARDL approach over other alternative methods have been extensively documented in the econometric literature. The main objective of the NARDL approach is to take into consideration both the short and long-run nonlinearity in the independent variables while maintaining all the advantages of the ARDL approach. The NARDL bounds testing approach to cointegration is based on the following asymmetric error-correction model:

$$
\begin{aligned}
& \Delta \ln T B_{t}=\phi_{0}+\phi_{1} \ln T B_{t-1}+\phi_{2} \ln Y_{t-1}+\phi_{3} \ln Y F_{t-1}+\phi_{4}^{+} \ln R E R_{t-1}^{+}+\phi_{4}^{-} \ln R E R_{t-1}^{-}+ \\
& \sum_{i=1}^{m} \gamma_{1 i} \Delta \ln T B_{t-i}+\sum_{i=0}^{n} \gamma_{2 i} \Delta \ln Y_{t-i}+\sum_{i=0}^{p} \gamma_{3 i} \Delta \ln Y_{t-i}+\sum_{i=0}^{q}\left(\gamma_{4 i}^{+} \Delta \ln R E R_{t-i}^{+}+\gamma_{4 i}^{-} \Delta \ln R E R_{t-i}^{-}\right)+e_{t}
\end{aligned}
$$

where $\Delta$ is the difference operator defined as $\Delta \mathrm{Z}_{\mathrm{t}}=\mathrm{Z}_{\mathrm{t}}-\mathrm{Z}_{\mathrm{t}-1}$. The coefficients $\phi_{4}^{+}$and $\phi_{4}^{-}$capture the long-run asymmetry

while $\gamma_{4 i}^{+}$and $\gamma_{4 i}^{-}$capture the short-run asymmetry.

The application of the nonlinear ARDL approach entails the following steps. In the first step, we estimate Eq.(11) using the standard OLS method. Second, we perform a test for the presence of a long-run relationship among the variables using the F test of the null hypothesis: $\phi_{1}=\phi_{2}=\phi_{3}=\phi_{4}^{+}=\phi_{4}^{-}=0$. The critical values are the same that those of the linear model with three regressors. If the computed F-test value falls below the lower bound critical value, then the null hypothesis of no cointegration cannot be rejected. If the computed F-statistic value is higher than the upper bound critical value, then there is evidence of cointegration among the variables. If it falls within the upper and lower bound values, there is no decision about the existence of cointegration. In the third step, we test for symmetry using Wald tests:

i) long-run symmetry where the null hypothesis is $\phi_{4}^{+}=\phi_{4}^{-}$, and ii) short-run symmetry in which the null hypothesis is

$\gamma_{4 i}^{+}=\gamma_{4 i}^{-}$for all $i$. Eq.(11) is reduced to the standard linear error-correction model if both null hypotheses of short and

long-run symmetry cannot be rejected. On the contrary, if the null hypotheses are rejected, then the model is asymmetric. There may be a short-run asymmetry, a long-run asymmetry, or both short and long run asymmetry in the relationship between real exchange rate and trade balance.

\subsection{Data Description}

The study uses annual time series data spanning the period from 1975 to 2017. The dependent variable is trade balance defined as the ratio of exports to imports. The explanatory variables are domestic real GDP in constant US dollar as a proxy for gross domestic income, world real GDP in constant US dollar as a proxy for foreign income, and real effective exchange rate. Data on the trade balance, domestic real GDP, and world real GDP were extracted from the 2019 World Development Indicators database of the World Bank. Data on the real effective exchange rate (RER) were sourced from the Central Bank of West African States (BCEAO). A real effective exchange rate is such that an increase (decrease) signifies a real appreciation (depreciation) of the domestic currency. For the empirical analysis, all variables were transformed into a natural logarithm.

Figure 1 depicts the trends of trade balance and real effective exchange rate over the sample period. It can be seen that both variables exhibit considerable fluctuations over the sample period. In particular, the real effective exchange rate has been appreciating since the devaluation of the CFA franc in 1994. Between 1994 and 2009, the real effective exchange rate appreciated by about $24 \%$ and started to depreciate from 2009. It is worth mentioning that structurally 
low inflation rate over the post-devaluation period helps limit the appreciation of the real effective exchange rate, which is still trading $25 \%$ below the 1993 level.

Trade balance (in log)

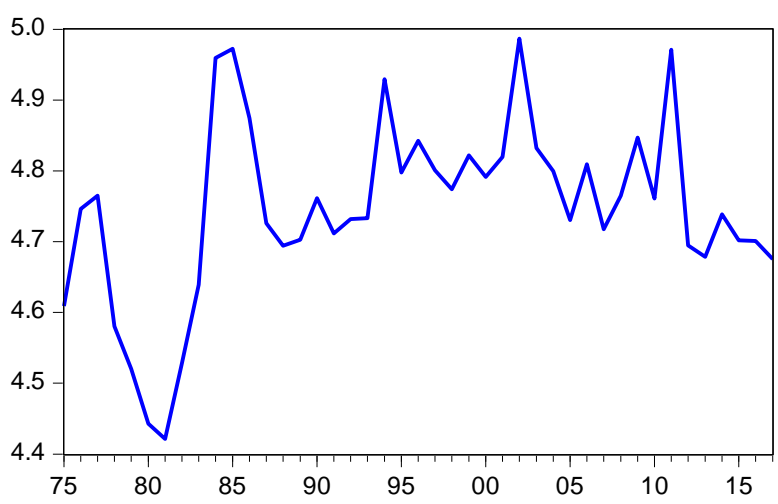

Real effective exchange rate (in log)

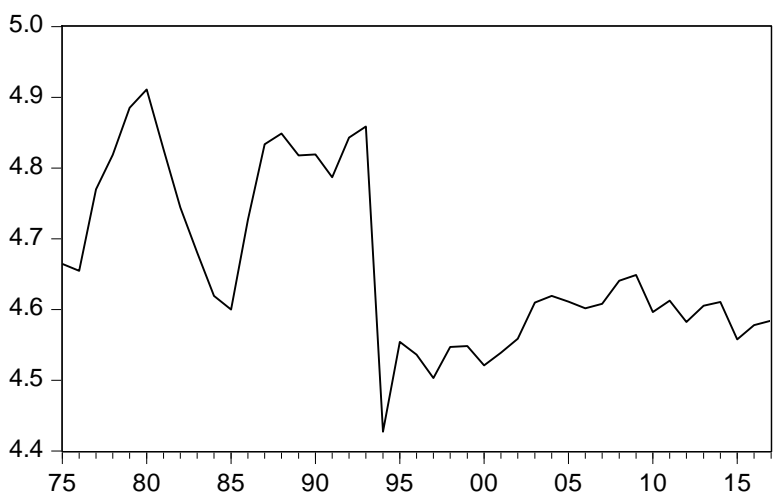

Figure 1. Trade balance and real exchange rate (in the log) over the period 1975-2017

Table 1 presents some descriptive statistics and correlations of the variables. Trade balance averages 4.746 over the sample period and ranges from 4.421 to 4.986 . The standard deviation shows the level of volatility in the variables. From the Table, foreign income is the most volatile while the real effective exchange rate is the less volatile. The Jarque-Bera statistic suggests that all the variables under study are normally distributed. The correlation matrix shows a positive and significant relationship between trade balance and foreign income. A negative and significant relationship exists between trade balance and real exchange rate. The correlation matrix also reveals a problem of collinearity between domestic income and foreign income, with a correlation value of 0.913 . For this reason, the foreign income variable was left out of the empirical analysis.

Table 1. Descriptive Statistics and Correlation Matrix

\begin{tabular}{|c|c|c|c|c|}
\hline Variables & $\ln \mathrm{TB}$ & $\ln \mathrm{Y}$ & $\ln Y F$ & lnRER \\
\hline \multicolumn{5}{|c|}{ Panel A: Summary statistics } \\
\hline Mean & 4.746 & 23.755 & 31.415 & 4.662 \\
\hline Median & 4.746 & 23.747 & 31.406 & 4.6125 \\
\hline Maximum & 4.986 & 24.399 & 32.015 & 4.911 \\
\hline Minimum & 4.421 & 23.326 & 30.772 & 4.427 \\
\hline Std. dev. & 0.127 & 0.237 & 0.367 & 0.122 \\
\hline Skewness & -0.410 & 0.868 & -0.032 & 0.477 \\
\hline Kurtosis & 3.479 & 3.463 & 1.783 & 2.095 \\
\hline Jarque-Bera & 1.620 & 5.794 & 2.660 & 3.098 \\
\hline Probability & 0.444 & 0.055 & 0.264 & 0.212 \\
\hline \multicolumn{5}{|c|}{ Panel B: Correlation matrix } \\
\hline $\operatorname{lnTB}$ & 1.000 & & & \\
\hline $\ln \mathrm{Y}$ & 0.101 & 1.00 & & \\
\hline $\operatorname{lnYF}$ & $0.308^{*}$ & $0.913^{*}$ & 1.000 & \\
\hline lnRER & $-0.588^{*}$ & $-0.499^{*}$ & $-0.569^{*}$ & 1.000 \\
\hline
\end{tabular}

\section{Empirical Results and Discussion}

As a first step of the empirical analysis, we determine the order of integration of the variables. This step is necessary to ascertain that none of the variables is integrated of order 2 since the ARDL bounds testing approach to cointegration is only applicable when the series are integrated of order zero or one. Consequently, we apply Phillips and Perron's (1988) and PDF-GLS (Elliott, Rothenberg, \& Stock, 1996) unit root tests. The results of these tests are reported in Table 2. Both tests are conclusively in favor of unit root for all variables in level but stationary for variables in first difference. Therefore, we can consider that all series are I(1) processes. Given this finding, the analysis goes forward with cointegration tests. 
Table 2. Results of unit root tests

\begin{tabular}{lccccc}
\hline & \multicolumn{2}{c}{ Phillips-Perron } & & PDF-GLS \\
\cline { 2 - 3 } \cline { 5 - 5 } Series & $\mathrm{C}$ & $\mathrm{C} / \mathrm{T}$ & & $\mathrm{C}$ & $\mathrm{C} / \mathrm{T}$ \\
\hline $\ln \mathrm{n}$ TB & -2.182 & -3.274 & & -1.746 & -3.164 \\
$\ln \mathrm{N}$ & 0.611 & -0.919 & & 1.870 & -1.742 \\
$\ln \mathrm{RER}$ & -2.287 & -3.138 & & $-2.293^{*}$ & -2.932 \\
$\Delta \operatorname{lnTB}$ & $-7.722^{*}$ & $-8.163^{*}$ & & $-5.850^{*}$ & $-6.832^{*}$ \\
$\Delta \ln \mathrm{N}$ & $-4.376^{*}$ & $-4.748^{*}$ & & $-2.843^{*}$ & $-3.784^{*}$ \\
$\Delta \operatorname{lnRER}$ & $-6.940^{*}$ & $-6.864^{*}$ & & $-7.018^{*}$ & $-7.027^{*}$ \\
\hline
\end{tabular}

Note: TB, Y, and RER denote trade balance, real GDP, and real effective exchange rate, respectively. The optimal lag structure of the PP test is chosen based on the Newey-West bandwidth with Bartlett weights. The optimal lag structure of the DF-GLS test is chosen based on the Schwarz Information Criterion. The 5\% critical values for the Phillips-Perron unit root tests are -2.932 and -3.520 for models $C$ and $C / T$ respectively. Those for the DF-GLS test are -1.949 and -3.190 for models $\mathrm{C}$ and $\mathrm{C} / \mathrm{T}$, respectively. * denotes rejection of the null hypothesis of unit root at the $5 \%$ level.

Table 3 displays the results of the bounds testing for asymmetric cointegration. The Table also reports the test results for long and short-run symmetry. The results of asymmetric cointegration, as calculated by the F-statistic, clearly reject the null hypothesis of no cointegration regardless of the term of asymmetry. This indicates the presence of a significant asymmetric long-run relationship between trade balance, domestic income, and real exchange rate. Furthermore, the Wald test strongly rejects the null of long-run symmetry. It fails, however, to reject the null of short-run symmetry. The F-statistic rejects the null hypothesis of no cointegration if we allow short-run symmetry and long-run asymmetry. Therefore, these findings suggest that the preferred model should combine long-run asymmetry in line with short-run symmetry relationship in the nonlinear ARDL model.

Table 3. Bounds Testing for Cointegration and Asymmetry Tests

\begin{tabular}{llll}
\hline Model & F-stat. & Long-run symmetry & Short-run symmetry \\
\hline NARDL with long and short run asymmetry & $8.331^{*}$ & $5.575^{*}[0.018]$ & $0.797[0.371]$ \\
NARDL with short-run symmetry & $8.604^{*}$ & $5.012^{*}[0.025]$ & - \\
\hline
\end{tabular}

Note: For $\mathrm{k}=2$, the $5 \%$ critical values (bounds) are 3.10 and 3.87. The asterisk ${ }^{*}$ denotes rejection of the null hypothesis at the $5 \%$ level.

Following these results, we next turn to estimate the nonlinear relationship between the variables. Table 4 presents the estimates of the slope coefficients that measure the degrees of real exchange rate pass-through. The long-run coefficients on $\operatorname{lnRER}{ }^{+}$and $\operatorname{lnRER}{ }^{-}$are -1.316 and -1.783 , respectively. These coefficients are statistically significant. Therefore, we conclude that a $1 \%$ increase in the real exchange rate results in a $1.316 \%$ decrease in the trade balance. Similarly, a $1 \%$ decrease in the real exchange rate leads to a $1.783 \%$ increase in the trade balance. Consequently, these findings indicate that trade balance responds stronger to negative shocks in real exchange rates (depreciation) than to positive ones (appreciations). 
Table 4. Long-run Estimation Results of Nonlinear ARDL Model

\begin{tabular}{llll}
\hline & \multicolumn{2}{l}{ The dependent variable is lnTB } & FMOLS \\
\cline { 2 - 4 } Regressors & ARDL & DOLS & $-0.409^{*}[-5.213]$ \\
\hline $\ln Y$ & $-0.348^{*}[-2.009]$ & $-0.370^{*}[-3.634]$ & $-0.641^{*}[-4.282]$ \\
$\operatorname{lnRER}{ }^{+}$ & $-1.316^{*}[-3.390]$ & $-0.102[-0.543]$ & $-1.236^{*}[-7.321]$ \\
$\operatorname{lnRER}{ }^{-}$ & $-1.783^{*}[-4.500]$ & $-0.661^{*}[-3.515]$ & $-0.301^{*}[-4.220]$ \\
D94 & $-0.371^{*}[-2.729]$ & $-0.136^{*}[-2.096]$ & $14.280^{*}[7.785]$ \\
Constant & $12.984^{*}[3.209]$ & $13.226^{*}[5.541]$ & 0.620 \\
\hline $\mathrm{R}^{2}$ & 0.615 & 0.851 & 42 \\
$n$ & 42 & 40 & $34.581^{*}[0.000]$ \\
\hline
\end{tabular}

Note: The dependent variable is the log of trade balance defined as the ratio of exports to imports. Y and RER denote real GDP and real effective exchange rate, respectively. The superscripts "+" and "-" denote positive and negative partial sums of the real effective exchange rate, respectively. Figures in brackets are $t$-statistics. The test for symmetry has the null hypothesis: $\operatorname{lnRER}{ }^{+}=\operatorname{lnRER}^{-}$, with $p$-values given in brackets. The asterisk ${ }^{*}$ indicates significance at the $5 \%$ level.

Further, the results show that domestic income significantly affects trade balance. The negative sign on the coefficient of income implies that an increase in domestic income will lead to increased demand for foreign goods, thus worsening the trade balance. The estimates indicate that a one percent increase in domestic income results in about a 0.4 percent decrease in the trade balance in the long-run. This finding is consistent with Adeniyi et al. (2011) who found a negative relationship between domestic income and trade balance in Ghana. It also endorses Genemo (2017) and Keho (2020) who found a negative relationship between domestic income and trade balance in selected African countries, and Cote d'Ivoire, respectively.

Based on the nonlinear ARDL estimation approach, we investigate the short-run effects of domestic income and real exchange rate on the trade balance. The results are portrayed in Table 5. The test for symmetry reports an F-statistic of 0.347 with a $p$-value of 0.558 , indicating the non-rejection of the null hypothesis of the symmetric short-run effect of real exchange rate on the trade balance. This confirms that trade balance responds asymmetrically to real exchange rate shocks only in the long-run. The short-run relationship between trade balance and the real exchange rate is symmetric.

Table 5. Short-run Estimation Results of Trade Balance Model

\begin{tabular}{|c|c|c|c|c|}
\hline & \multicolumn{2}{|c|}{ Linear model } & \multicolumn{2}{|c|}{ Nonlinear model } \\
\hline & Coef. & Prob. & Coef. & Prob. \\
\hline$\Delta \ln Y$ & $-0.615^{*}$ & 0.005 & $-0.662^{*}$ & 0.005 \\
\hline$\triangle \operatorname{lnRER}$ & $-0.916^{*}$ & 0.000 & - & - \\
\hline$\Delta \operatorname{lnRER}{ }^{+}$ & - & - & $-0.778^{*}$ & 0.007 \\
\hline$\Delta \operatorname{lnRER}{ }^{-}$ & - & - & $-0.968^{*}$ & 0.000 \\
\hline ECT & $-0.662^{*}$ & 0.000 & $-0.671^{*}$ & 0.000 \\
\hline Test for symmetry & - & - & 0.347 & 0.558 \\
\hline
\end{tabular}

Note: The dependent variable is the first difference of the log of the trade balance, defined as the ratio of exports to imports. Y and RER denote real GDP and real effective exchange rate, respectively. The superscripts “+” and "-" denote positive and negative partial sums of the real effective exchange rate, respectively. ECT denotes the error correction term. The test for symmetry has the null hypothesis: $\Delta \operatorname{lnRER}{ }^{+}=\Delta \operatorname{lnRER}^{-}$. The asterisk ${ }^{*}$ denotes significance at the $5 \%$ level. 
As can be seen from the estimation of the linear model, the coefficient on the first lag of the error-correction term is negative and statistically significant, confirming the existence of a long-run relationship between the variables. Furthermore, domestic income growth significantly and negatively impacts the trade balance in the short-run. This finding supports the Keynesian theory that an increase in income leads to increased demand for foreign goods, thus deteriorating the trade balance. The results also reveal a negative and significant coefficient on the real effective exchange rate, indicating that real exchange rate depreciation causes an improvement in the trade balance in the short-run.

\section{Conclusion}

This paper examines the asymmetric impact of real exchange rate on the trade balance in Cote d'Ivoire. To this end, it employs the nonlinear autoregressive distributed lag approach suggested by Shin et al. (2014). This approach filters appreciations from depreciations and estimates their respective effects on trade balance. The trade balance is defined by the ratio of exports to imports. Using annual data covering the period 1975-2017, the empirical results provide evidence in favor of the asymmetric relationship between trade balance and real effective exchange rate in Cote d'Ivoire. We found that trade balance reacts asymmetrically to the real effective exchange rate changes in the long-run, while the short-run effect is symmetric. Furthermore, the estimates indicate that trade balance responds stronger to depreciations in real exchange rate than to appreciations. On the other hand, domestic income significantly and negatively impacts the trade balance in both the short and long run. This finding supports the Keynesian theory that an increase in income leads to increased demand for foreign goods, thus worsening the trade balance. These findings imply that the government of Cote d'Ivoire should concentrate its policy efforts towards import substitution strategy that will promote the production of currently imported goods locally, thereby reducing imports and improving the trade balance.

This study has considered the aggregate trade balance of Cote d'Ivoire with the rest of the world. Cote d'Ivoire has different export and import prices with its trade partners. Using aggregated trade data the empirical results may suffer from aggregation bias. Therefore, future research should be conducted at a disaggregated level using the bilateral trade balance of Cote d'Ivoire with its major trade partners.

\section{References}

Adeniyi, O., Omisakin, O., \& Oyinlola, A. (2011). Exchange Rate and Trade Balance in West African Monetary Zone: Is There a J-Curve? The International Journal of Applied Economics and Finance, 5(3), 167-176. https://doi.org/10.3923/ijaef.2011.167.176

Akoto, L., \& Sakyi, D. (2019). Empirical Analysis of the Determinants of Trade Balance in Post-liberalization Ghana. Foreign Trade Review, 54(3), 177-205. https://doi.org/10.1177/0015732519851632

Akpansung, A. O., \& Babalola, S. J. (2013). Effects of Real Exchange Rate on Trade Balance: Empirical Evidence from Nigeria. Asian Journal of Empirical Research, 3(5), 605-617.

Alege, P. O. \& Osabuohien, E. S. (2015). Trade-Exchange Rate Nexus in Sub-Saharan African Countries: Evidence from Panel Cointegration Analysis. Foreign Trade Review, 50(3), 151-167. https://doi.org/10.1177/0015732515589440

Aliyu, A. J., \& Tijjani, S. M. (2015). Asymmetric Cointegration between Exchange Rate and Trade Balance in Nigeria. Cogent Economics \& Finance, 3(1), 1045213. https://doi.org/10.1080/23322039.2015.1045213

Amzath, A., Drama, B. G. H., \& Shen, Y. (2010). The Effects of Real Exchange rate on Trade Balance in Cote d'Ivoire: Evidence from the Cointegration Analysis and Error-Correction Models. Journal of Applied Research in Finance, 2(3), 44-66.

Anning, L., Riti, J. S., \& Yapatake, K. T. (2015). Exchange Rate and Trade Balance in Ghana- Testing the Validity of the Marshall-Lerner Condition. International Journal of Development and Emerging Economics, 3(2), 38-52.

Arize, A. C., Malindretos, J., \& Igwe, E. U. (2017). Do Exchange Rate Changes Improve the Trade Balance: An Asymmetric Nonlinear Cointegration Approach. International Review of Economics \& Finance, 49(C), 313-326. https://doi.org/10.1016/j.iref.2017.02.007

Baharumshah, A. Z. (2001). The Effect of Exchange Rate on Bilateral Trade Balance: New Evidence from Malaysia and Thailand. Asian Economic Journal, 15(3), 291-312. https://doi.org/10.1111/1467-8381.00135

Bahmani-Oskoee, M. (2001). Nominal and Real Effective Exchange Rates of Middle Eastern Countries and Their Trade Performance. Applied Economics, 33(1), 103-111. https://doi.org/10.1080/00036840122490

Bahmani-Oskooee, M., \& Arize, A. C. (2019). U.S.-Africa Trade Balance and the J-curve: An Asymmetry Analysis. The International Trade Journal, 33(4), 322-343. https://doi.org/10.1080/08853908.2019.1570881

Bahmani-Oskooee, M. (1991). Is There a Long-Run Relation between the Trade Balance and the Real Effective 
Exchange Rate of LDCs? Economics Letters, 36, 403-407. https://doi.org/10.1016/0165-1765(91)90206-Z

Bahmani-Oskooee, M., \& Baek, J. (2019). Asymmetry Cointegration and the J-curve: New Evidence from Korean Bilateral Trade Balance Models with her 14 Partners. Journal of the Asia Pacific Economy, 24(1), 66-81. https://doi.org/10.1080/13547860.2018.1469589

Bahmani-Oskooee, M., \& Fariditavana, H. (2015). Nonlinear ARDL Approach, Asymmetric Effects and the J-curve. Journal of Economic Studies, 42(3), 519-530. https://doi.org/10.1108/JES-03-2015-0042

Bahmani-Oskooee, M., \& Fariditavana, H. (2016). Nonlinear ARDL Approach and the J-Curve Phenomenon. Open Economies Review, 27(1), 51-70. https://doi.org/10.1007/s11079-015-9369-5

Bahmani-Oskooee, M., \& Fariditavana, H. (2020). Asymmetric Cointegration and the J-Curve: New Evidence from Commodity Trade between the U.S. and Canada. International Economics and Economic Policy, 17(2), 427-482. https://doi.org/10.1007/s10368-019-00447-0

Bahmani-Oskooee, M., \& Gelan, A. (2020). The South Africa-U.S. Trade and the Real Exchange Rate: Asymmetric Evidence from 25 Industries. South African Journal of Economics, 88(2), 186-203. https://doi.org/10.1111/saje.12242

Bahmani-Oskooee, M., \& Kanitpong, T. (2017). Do Exchange Rate Changes have Symmetric or Asymmetric Effects on the Trade Balances of Asian Countries? Applied Economics, 49(46), 4668-4678. https://doi.org/10.1080/00036846.2017.1287867

Bahmani-Oskooee, M., \& Ratha, A. (2004). The J-Curve: A Literature Review. Applied Economics, 36(13), 1377-1398. https://doi.org/10.1080/0003684042000201794

Bahmani-Oskooee, M., \& Arize, A. C. (2020). Asymmetry Cointegration and the J-curve: New Evidence from Africa. Journal of Economic Studies, 47(5), 969-984. https://doi.org/10.1108/JES-09-2018-0333

Bahmani-Oskooee, M., Bose, N., \& Zhang, Y. (2019). An Asymmetric Analysis of the J-Curve Effect in the Commodity Trade between China and the US. The World Economy, 42(10), 2854-2899. http://dx.doi.org/10.1111/twec.12829

Boyd, D., Caporale, G. M., \& Smith, R. (2001). Real Exchange Rate Effects on the Balance of Trade: Cointegration and the Marshall-Lerner Condition. International Journal of Finance and Economics, 6(3), 187-200. https://doi.org/10.1002/ijfe.157

Bussière, M., Callegari, G., Ghironi, F., Sestieri, G., \& Yamano, N. (2013). Estimating Trade Elasticities: Demand Composition and the Trade Collapse of 2008-2009. American Economic Journal: Macroeconomics, 5(3), 118-151. https://doi.org/10.1257/mac.5.3.118

Caporale, G. M., Gil-Alana, L., \& Mudida, R. (2015). Testing the Marshall-Lerner Condition in Kenya. South African Journal of Economics, 83(2), 253-268. https://doi.org/10.1111/saje.12052

Eke, I. C., Eke, F. A., \& Obafemi, F. N. (2015). Exchange Rate Behaviour and Trade Balances in Nigeria: An Empirical Investigation. International Journal of Humanities and Social Science, 5(8), 71-78.

Elliott, G., Rothenberg, T. J., \& Stock, J. H. (1996). Efficient Tests for an Autoregressive Unit Root. Econometrica, 64(4), 813-836. https://doi.org/10.2307/2171846

Enders, W., \& Siklos, P. L. (2001). Cointegration and Threshold Adjustment. Journal of Business and Economic Statistics, 19(2), 166-176. https://doi.org/10.1198/073500101316970395

Genemo, K. B. (2017). Effect of Exchange Rate on Trade Balance in Major East African Countries: Evidence from Panel Cointegration. European Business and Management, 3(6), 95-104. https://doi.org/10.11648/j.ebm.20170306.11

Igue, N. N., \& Ogunleye, T. S. (2014). Impact of Real Exchange Rate on Trade Balance in Nigeria. African Development Review, 26(2), 347-357. https://doi.org/10.1111/1467-8268.12086

Iyke, N. B., \& Ho, S. Y. (2017). The Real Exchange Rate, the Ghanaian Trade Balance, and the J-curve. Journal of African Business, 18(3), 380-392. https://doi.org/10.1080/15228916.2017.1315706

Junz, H., \& Rhomberg, R. (1973). Price Competitiveness in Export Trade among Industrial Countries. American Economic Review, 63(2), 412-418. https://doi.org/10.17016/IFDP.1973.22

Kale, P. (2001). Turkey's Trade Balance in the Short and the Long Run: Error-Correction Modeling and Cointegration. The International Trade Journal, 15(1), 27-56. https://doi.org/10.1080/088539001300005440

Kamugisha, G., \& Assoua, J. E. (2020). Effects of a Devaluation on Trade Balance in Uganda: An ARDL Cointegration Approach. International Journal of Economics and Finance, 12(7), 42-53. https://doi.org/10.5539/ijef.v12n7p42 
Keho, Y. (2020). Impact of Foreign Direct Investment on Trade Balance: Evidence from Cote d'Ivoire. International Journal of Economics and Finance, 12(7), 113-124. https://doi.org/10.5539/ijef.v12n7p113

Keho, Y. (2021). Real Exchange Rate and Trade Balance Dynamics in Cote d'Ivoire. International Journal of Economics and Financial Issues, 11(1), 61-70. https://doi.org/10.32479/ijefi.10857

Krueger, A. D. (1983). Exchange Rate Determination. Cambridge University Press, Cambridge.

Lal, A., \& Lowinger, T. (2002). The J-curve: Evidence from East Asia. Journal of Economic Integration, 17(2), 397-415. https://doi.org/10.11130/jei.2002.17.2.397

Lerner, A. P. (1944). The Economics of Control: Principles of Welfare Economics. London: Macmillan Company, N.Y.

Loto, M. A. (2011). Does Devaluation Improve the Trade Balance of Nigeria: A Test of the Marshall Lerner Condition. Journal of Economics and International Finance, 3(11), 624-633.

Magee, S. P. (1973). Currency Contracts, Pass Through, and Devaluation. Brookings Papers of Economic Activity, 1, 303-325. https://doi.org/10.2307/2534091

Marshall, A. (1923). Money, Credit and Commerce. London: Macmillan \& CO.

Meniago, C., \& Eita, J. H. (2017). The Effects of Exchange Rate Changes on Sub-Saharan Africa Trade. International Journal of Sustainable Economy, 9(3), 213-230. https://doi.org/10.1504/IJSE.2017.085065

Musila, J. W., \& Newark, J. (2003). Does Currency Devaluation Improve the Trade Balance in the Long Run? Evidence from Malawi. African Development Review, 15(2-3), 339-352. https://doi.org/10.1111/j.1467-8268.2003.00076.x

Nathaniel, S. P. (2020). Does Exchange Rate Have Asymmetric Impact on Trade Balance? Fresh Insights from Combined Cointegration. Studies in Business and Economics, 15(1), 259-269. https://doi.org/10.2478/sbe-2020-0019

Ogbonna, B. C. (2011). The Impact of Exchange Rate Variations on Trade Balance: Evidence from Nigeria, 1970-2005. Journal of Research in National Development, 9(2), 393-403.

Ogbonna, B. C. (2016). Trade Balance Effect of Exchange Rate Devaluation in Benin Republic: The Empirical Evidence. IOSR Journal of Economics and Finance, 7(2), 33-43.

Ogundipe, A. A., Ojeaga, P., \& Ogundipe, O. M. (2013). Estimating the Long Run Effects of Exchange Rate Devaluation on the Trade Balance of Nigeria. European Scientific Journal, 9(25), 233-249. https://doi.org/10.19044/esj.2013.v9n25p\%p

Oyinlola, M. A., Omisakin, O. A., \& Adeniyi, O. A. (2013). An Empirical Re-examination of Exchange Rate-Trade Balance Nexus in Nigeria. African Journal of Economic Policy, 20(2), 123-141.

Pesaran, M. H., Shin, Y., \& Smith, R. J. (2001). Bounds Testing Approaches to the Analysis of Level Relationships. Journal of Applied Econometrics, 16(3), 289-326. https://doi.org/10.1002/jae.616

Phillips, P. C. B., \& Perron, P. (1988). Testing for a Unit Root in a Time Series Regression. Biometrika, 75(2), 335-346. https://doi.org/10.1093/biomet/75.2.335

Rawlins, G. (2011). Currency Depreciations and the Trade Balance: The Case of Sub-Sahara Africa. Journal of Applied Business and Economics, 12(6), 132-148.

Rose, A. K. (1990). Exchange Rates and the Trade Balance: Some Evidence from Developing Countries. Economics Letters, 34(3), 271-275. https://doi.org/10.1016/0165-1765(90)90130-S

Rose, A. K., \& Yellen, J. L. (1989). Is there a J-curve? Journal of Monetary Economics, 24(1), 53-68. https://doi.org/10.1016/0304-3932(89)90016-0

Shin, Y., Yu, B., \& Greenwood-Nimmo, M. (2014). Modelling Asymmetric Co-integration and Dynamic Multipliers in a Nonlinear ARDL Framework. In W. Horrace \& R. Sickles (Eds.), The Festchrift in Honor of Peter Schmidt: Econometric Methods and Applications (pp. 281-314). New York: Springer. https://doi.org/10.1007/978-1-4899-8008-3_9

Umoru, D., \& Oseme, A. (2013). Trade Flows and Exchange Rate Shocks in Nigeria: An Empirical Result. Asian Economic and Financial Review, 3(7), 948-977.

Upadhyaya, K. P., \& Dhakal, D. (1997). Devaluation and the Trade Balance: Estimating the long run effect. Applied Economics Letters, 4(6), 343-345. https://doi.org/10.1080/135048597355276

Yazgan, M. E., \& Ozturk, S. S. (2019). Real Exchange Rates and the Balance of Trade: Does the J-curve Effect Really Hold? Open Economies Review, 30, 343-373. https://doi.org/10.1007/s11079-018-9510-3 
Yol, M. A., \& Baharumshah, A. Z. (2007). Estimating Exchange Rate and Bilateral Trade Balance Relationships: The Experience of Sub-Saharan African Countries. South African Journal of Economics, 75(1), 35-51. https://doi.org/10.1111/j.1813-6982.2007.00104.x

\section{Copyrights}

Copyright for this article is retained by the author(s), with first publication rights granted to the journal.

This is an open-access article distributed under the terms and conditions of the Creative Commons Attribution license which permits unrestricted use, distribution, and reproduction in any medium, provided the original work is properly cited. 